D. Molnár Éval - Gál Zita ${ }^{2}$

${ }^{1}$ SZTE Neveléselmélet Tanszék

${ }^{2}$ SZTE Pszichológiai Intézet

\title{
Egyetemi tanulmányaikat megkezdő hallgatók tanulási mintázata és tanulói profilja
}

Napjainkban egyre nagyobb figyelem irányul az egyetemi lemorzsolódás jelenségére, hiszen ennek gazdasági, társas és pszichológiai következményei is vannak, ami az egész társadalomra nézve ártalmas lehet. Noha több kutatást is végeztek az utóbbi idókben ezen a téren, a lemorzsolódás okai és faktorai nem meghatározhatók egyértelmúen (Tinto, 2010). A lemorzsolódáshoz kapcsolódó elméleti modellek és kutatások többnyire gazdasági, szervezeti, szociológiai és pszichológiai tényezóket vontak be vizsgálati szempontként (Braxton és Hirschy, 2005), valamint vizsgálták a családi háttér, az egyetemi

oktatási szinvonal és a tanulói egyéni jellemzók szerepét

(Forbes és Wickens, 2005), azonban még nem ismert olyan egységes, mindenki által elfogadott modell, ami teljes mértékben megmagyarázná, hogy a hallgatók miért és milyen okokkal hagyják félbe egyetemi tanulmányaikat. A hallgatók tanulása, tanulási stratégiái, szokásai, tanulási énképe, motivációja, a tanuláshoz való hozzáállásának jellemzói az egyik gyakran vizsgált lényeges

szempont, ami alapvetố kutatási területként jelenik meg a lemorzsolódás-vizsgálatokban (l. Tanaka és Murayama, 2014).

A tanulási stratégiák, szokások szerepe a sikeres tanulásban

A z egyetemi tanulmányok, a kurzusok és szemináriumok teljesítése sok hallgató számára szorongással és stresszel járó időszak lehet (Alkan, 2014), ami hatványozottan jelenhet meg abban az esetben, ha a hallgatók nem rendelkeznek hatékony tanulási stratégiákkal és tanulási szokásokkal. A tanulás kutatása régre nyúlik vissza, és míg a kezdetekkor föként az információ elrendezésével, feldolgozásával kapcsolatos megközelítések láttak napvilágot (1. Entwistle és Ramsden, 1983), napjainkban ez kiegészült a metakognitív és az önszabályozó komponensek bevonásával (Pintrich, 2004).

A tanulási stratégiák tipizálásában többféle megközelítés is létezik (1. Hartwig és Dunlowsky, 2012; Nagy és D. Molnár, 2017), azonban az egyik legismertebb és átfogóbb kategorizálás Pintrich (1999) nevéhez köthető. Felosztásában kognitív, metakognitív és szabályozó, illetve forrás-menedzselő stratégiák szerepelnek. A kognitív stratégiák az információk kiválasztásával, kódolásával és elrendezésével kapcsolatosak (Weinstein, 
Husman, és Dierking, 2000). A metakognitív és szabályozó stratégiák a tervezésre, a tanulási folyamat monitorozására és értékelésére vonatkoznak (Winne és Perry, 2000). A forrásmenedzselő stratégiák a külső (pl. környezeti tényezők, idő) és belső (pl. szorgalom, erőfeszítés) erőforrások kezelését foglalják magukban (Pintrich, 2000).

A hatékony stratégiahasználat azt jelenti, hogy a tanulók számos tanulási stratégiát ismernek, azokat személyre szabottan és a tanulási környezetnek megfelelően, megfontoltan tudják alkalmazni (Paris és Paris, 2001). Ugyanakkor az adekvát stratégiahasználat nem csak az információ megszerzésére irányul, hanem alkalmazásuk révén a tanulás különbözö területeinek a szabályozása is megvalósul a motiváció, az alkalmazott módszerek, a teljesítmény, a szociális és a környezeti kontextusra vonatkozóan egyaránt, ami pozitív összefüggést mutat a tanulmányi eredményességgel (Linnenbrink és Pintrich, 2002).

Ugyanakkor léteznek nem hatékony (maladaptív) tanulási stratégiák is, amik leginkább a motiváció és a szelf szempontjából közelíthetők meg, melyhez a „célmegfogalmazások, a különböző motívumfajták, az énre vonatkozó megítélések [...], és a különböző kontroll-tevékenységek" tartoznak (Molnár, 2002, p. 65). Ezen komponensek a Pintrich-féle (2000) tipizálásban a metakognitív és szabályozó, valamint a forrásmenedzselő stratégiák kategóriájába tartoznak.

A maladaptív stratégiák olyan stratégiák, melyek többnyire aláássák és gátolják a sikeres teljesítmény elérését (Urdan és Midgley, 2001), mint például az önhátráltatás, a passzív halogatás, a védekező pesszimizmus, perfekcionizmus. Ezeket a stratégiákat többnyire olyan esetekben alkalmazzák a tanulók, amikor túl nehéz feladattal állnak szembe, vagy amikor kevés az esély a sikeres feladatvégzéshez, vagy amikor az értékelés által veszélyeztetve érzik énképüket, önértékelésüket, vagy ha kellemesebb tevékenységgel foglalkoznának, mint a tanulás (1. Nagy és D. Molnár, 2017).

A halogatás az egyetemista diákok körében nagyon gyakori, a megkérdezettek fele halogat rendszeresen, amiből problémái

A maladaptív stratégiák olyan stratégiák, melyek többnyire aláássák és gátolják a sikeres teljesítmény elérését (Urdan és Midgley, 2001), mint például az önhátráltatás, a passzív halogatás, a védekezó peszszimizmus, perfekcionizmus. Ezeket a stratégiákat többnyire olyan esetekben alkalmazzák. a tanulók, amikor túl nehéz feladattal állnak szembe, vagy amikor kevés az esély a sikeres feladatvégzéshez, vagy amikor az értékelés által veszélyeztetve érzik énképüket, önértékelésüket, vagy ha kellemesebb tevékenységgel foglalkoznának, mint a tanulás (l. Nagy és D. Molnár, 2017). származnak (Eckert, Ebert, Lehr, Sieland és Berking, 2016). Bár a hallgatók az okok között gyakran említik a nyomás alatti tanulás preferenciáját, általában jellemző rájuk az alacsony önértékelés és szorongás. A halogatás alkalmazásának számos negatív következménye lehet; kiderült, hogy az önhátráltató egyetemistáknak negatívabb az énképe, problémát jelent számukra az önszabályozás, alacsonyabb az önhatékonyságuk, valamint több felületes tanulási stratégiát alkalmaznak, mint azok, akik nem halogatnak (Gadbois és Sturgeon, 2011). Ugyanakkor az utóbbi időben egyre több kutatás hívja fel a figyelmet arra, hogy a halogatásnak létezik egy adaptív formája is, mely nem okoz szorongást és nem korrelál negatívan a tanulmányi eredményekkel (Jadidi, Mohammadkhanib és Tajrish, 2011). 


\section{A tanulási, én- attitüdök és a motiváció szerepe a lemorzsolódás elkerülésében}

Az egyetemi diákok közt nagy különbségek vannak a tekintetben, hogy mennyire tartják fontosnak a tanulást, milyen tanulási célokkal rendelkeznek és mennyire elégedettek az oktatás színvonalával, valamint saját teljesítményükkel (Ketonen, Malmberg, Salmela-Aro, Muukkonen, Tuominen és Lonka, 2018). Nemzetközi kutatásokban bizonyított, hogy a megértésre törekvés, az elsajátítási motiváció, a személyes tanulási célok pozitív összefüggést mutatnak az egyetemi tanulmányokkal és teljesítménnyel (Tanaka és Murayama, 2014; Ketonen, Dietrich, Moeller, Salmela-Aro és Lonka, 2018). Továbbá az egyetem iránti pozitív attitüd, a tanulás és az egyetemi légkör iránti elköteleződésnek fontos szerepe van a kiégés, az alacsony teljesítmény és a lemorzsolódás elkerülésében (Wang és Eccles, 2012).

A tanulási motívumok közül elsősorban a pozitív motivációs beállítódást érdemes kiemelni, mint például a magas önhatékonyság, a tanulás értékként való felfogása, a személyes tanulási célok megléte, az alacsony szorongás, amik összefüggnek a tudatosabb és kitartóbb feladatvégzéssel és hatékony akadémiai teljesítménnyel (Tanaka és Murayama, 2014). Fontos, hogy az egyetemisták személyesen megfogalmazott, jól körülhatárolt célokkal rendelkezzenek, amik befolyásolják az egyetemi éveik alatt a tanulásukat. Egyrészt a céljaik irányítják a viselkedésüket a releváns tevékenység kiválasztásában, másrészt szabályozzák az erőkifejtést és befektetett energiát, harmadrészt a célok hatást gyakorolnak a kitartásra is, főként olyan esetekben, amikor nincs elég idő a feladat elvégzésére (Latham és Locke, 1991). A tanulási célok tipizálásában az utóbbi időkben jól ismert a kétszer kettes felosztás: az elsajátítási (a tudás, képességek fejlesztése) és teljesítményre irányuló célokat a megközelítő/kereső és kerülő kategóriák mentén lehet tovább osztályozni (1. D. Molnár, 2013; Fejes, 2015).

Az akadémiai önhatékonyság (hit abban, hogy sikeresen véghez tudja vinni a tanulást) vizsgálata szintén meghatározó a hatékony tanulás kapcsán. Kimutatták, hogy akiknek magas az önhatékonyságuk, azok elkötelezettebbek a tanulási feladatok iránt, több szabályozó stratégiát használnak, kitartóbbak (Wolters, 2003), jobban figyelmen kívül tudják hagyni az ellentétes nyomásokat, hatékonyabban nyomon tudják követni tevékenységüket, reflexívebbek saját teljesítményüket illetően (Bandura, 1995), és jobb eredményeket érnek el, mint azok a tanulók, akik kevésbé biztosak képességeikben (Zimmerman, 1999).

A negatív tanulási attitüd, az alacsony önhatékonyság és énkép, valamint a magas tesztszorongás ugyanakkor összefüggést mutat a nem-releváns feladatmegoldásokkal és az alacsony akadémiai teljesítménnyel (Ketonen és mtsai, 2018). Ehhez kapcsolódik az a kutatási eredmény is, miszerint az utóbbi időkben észrevehető az újabb diplomák megszerzésének tendenciája az egyetemisták körében, aminek egyik magyarázata lehet a munkába állástól és az önálló felnőtt élet megkezdésétől való félelem (Gadbois és Sturgeon, 2011).

\section{A kutatás célja}

Kutatásunkban az egyetemre belépő hallgatók bemeneti kompetenciamérésének keretében (1. Molnár és Csapó, 2019; Csapó és Molnár, 2017), kérdőíves vizsgálattal terveztük megvizsgálni (1) az egyetemi tanulmányaikat kezdő hallgatók tanulási mintázatát; (2) a tanulási mintázat összefüggéseit a kognitív képességekkel és az egyetemi eredményességgel; illetve (3) a lemorzsolódás szempontjából veszélyeztetett csoportok beazonosítását a hallgató profilok alapján. 


\title{
Az empirikus vizsgált módszerei
}

\author{
A minta bemutatása
}

A vizsgálatban a Szegedi Tudományegyetem elsőéves egyetemi hallgatói vettek részt, összesen 1359 fö (életkori átlag= 19,9, szórás=2,52). Nemek tekintetében 702 férfi (51,7\%), míg 656 nő (48,3\%) vett részt a vizsgálatban (egy főnél nincs nemre vonatkozó adatunk).

\section{Mérőeszközök}

A bemeneti kompetenciamérés során a hallgatók tanulási mintázatát kérdőíves eljárással végeztük. A kérdőíves vizsgálat során több kérdőívből állítottuk össze azt a komplex kérdöívesomagot (TAMS - Tanulási attitüdök, motívumok és stratégiák, D. Molnár és Gál, 2017), melynek segítségével feltérképeztük a hallgatók tanulási stratégiáit, tanulási motívumait, tanulási attitüdjeit és én-attitüdjeit.

A kérdőívcsomagban szerepelt az Önszabályozott Tanulás Kérdőív (D. Molnár, 2013), melynek két fó alskálája a tanulási stratégiákat és a tanulási motívumokat vizsgálja. Ezáltal feltérképezhető, hogy a hallgatók milyen tanulási stratégiákat alkalmaznak, illetve a tanulásuk során mennyire motiváltak. Az állításokat ötfokú Likert-skálán kellett értékelnie a hallgatóknak. A kérdőív Tanulási stratégiák alskálája 25 itemet, míg a Tanulási motívumok alskálája 21 itemet tartalmaz. A tanulási stratégiák három fó csoportra bonthatók, a kognitív stratégiákra, a metakognitív stratégiákra, továbbá az erőforrások kihasználására. A kognitív stratégiákhoz tartozik a megtanulandó anyagok ismételgetéssel történő rögzítése, azaz a memorizálás, a tananyag megszervezése/kidolgozása, melynek során úgy tervezik meg a tananyagot, hogy azt számukra a legkönnyebb legyen elsajátítani. A metakognitív stratégiák közé tartoznak azok az eljárások, melynek során a tanulási folyamat kontrollálása, a folyamat megtervezése, monitorozása, az időgazdálkodás valósul meg. A belső és külső erőforrások használata a tanulás során azt jelenti, hogy a hallgató a tanulása során milyen erőforrásokat mozgósít a tananyag elsajátítása érdekében, így ide tartozik az erőfeszítés-kontroll, a segítségkérés másoktól, a feladatok halogatása, az érzelmekre való hagyatkozás, a körülményekre való hagyatkozás, illetve a túlkészülés. A kérdöív másik alskálájához, a tanulási motívumokhoz tartoznak azok a tényezők, amelyek azt vizsgálják, mi miatt tanulnak a hallgatók, miért kezdik meg és tartják fenn a tanulásukat, és mennyire bíznak abban, hogy meg tudnak tanulni egy tananyagot. A tanulási motívumok közé az elsajátítási motívum, a teljesítménykereső és teljesítménykerülő motívum, a szóbeli megnyilvánulásoktól való szorongás, illetve a pozitív és a negatív önhatékonyság skálái tartoznak (D. Molnár, 2013).

A tanulási és én-attitüdök közé soroltuk azokat a tényezőket, amelyek a hallgatók tanulással és saját magukkal kapcsolatos viszonyulását mérték. A kérdőívcsomag ezen részének kialakításakor a 2015-ös PISA mérésben alkalmazott tanulói kérdőívet vettük alapul, melyben a tanulók saját magukról és a tanuláshoz füződő viszonyukkal kapcsolatos kérdések szerepeltek (OECD, 2016). Ezek közül a PISA mérésben használt változók közül az én-attitüdre és a tanulási attitüdre vonatkozó kérdéseket emeltük ki és alakítottuk át aszerint, hogy az egyetemre belépő hallgatók életkori és tanulási sajátosságaihoz illeszkedjenek. A tanulási attitüdre vonatkozóan a szorgalomra (5 item), a feladatokkal kapcsolatos szervezésre, tervezésre ( 5 item), a számonkérési helyzetekben mutatott tesztszorongásra (5 item), az akadémiai önhatékonyságra (5 item), továbbá olyan társas helyzetekben mutatott jellemzőkre kérdeztünk rá, ami a társakkal kapcsolatos együttmüködést, vezetést és tárgyalási helyzetekre vonatkozik (18 item). A hallgatók saját 
magukkal kapcsolatos attitüdjei esetében olyan kérdőívtételeket alkalmaztunk, melyek általánosságban az önmagukhoz való viszonyulásukra vonatkoznak, így az élettel való megelégedést ( 7 item), a különböző problémahelyzetek iránti nyitottságot, a problémahelyzetekhez való viszonyulást (5 item), a feladathelyzetben, problémahelyzetben megjelenő kitartást (5 item), továbbá a rugalmasságot, vagyis a váratlan szituációkhoz való rugalmas alkalmazkodást ( 8 item) mértük. Minden terület esetében ötfokú Likert-skálát alkalmaztunk ( 1 - egyáltalán nem értek egyet, 5 - teljesen egyetértek).

A TAMS kérdöív-csomag mellett több kognitív képesség is felmérésre került, valamint rendelkezésünkre állnak az érettségi adatok, a felvételi pontszám is (1. Molnár, 2019; Molnár és Csapó, 2019; Pásztor, 2019; Hódi és Tóth, 2019).

\section{Eljárás}

A kérdőív kitöltése az eDia online teszt-platformján (Molnár, Makay és Ancsin, 2018) történt, egységesen megszervezett mérés keretében, az SZTE József Attila Tanulmányi és Információs Központ számítógéptermében 2017 szeptemberében.

\section{Eredmények}

\section{A hallgatók tanulási jellemzői}

A vizsgálat során ellenőriztük, hogy a mintánkba kerülő hallgatókra általánosságban milyen tanulási stratégiák és motívumok jellemzők.

A tanulási stratégiák eloszlása (1. táblázat) esetében a kognitív stratégiák közül a memorizálás magas szintje a hallgatók többségére, 74,2\%-ára volt jellemző a mintánkban, vagyis a tananyag ismételgetéssel történő rögzítés nagy arányban jellemző az egyetemre belépö hallgatókra. A hallgatók 26,2\%-ára alacsony, 41,3\%-ára közepes, míg 32,5\%-ára magas szinten jellemző tanulásuk során a tananyag megszervezése/kidolgozása. A metakognitív stratégiák közül a tervezés magas szintje a hallgatók 60,1\%-ára jellemzö, míg a tanulási folyamat monitorozásának alacsony, közepes és magas szintje hasonló arányban jellemző a hallgatókra, ez esetben nem találtunk jelentős különbséget a megoszlásban. A belső és külső erőforrások tekintetében a hallgatók többségére a magas szintü erőfeszítés-kontroll (55,4\%), magas szintű segítségkérés $(68,5 \%)$ jellemző a tanulási folyamat során. A tananyag elsajátításának halogatása közepes mértékben jellemző a hallgatók 46,2\%-ára, míg magas szinten a hallgatók 34,6\%-ára, vagyis a hallgatók nagy többsége legalább valamilyen szinten a halogatás stratégiáját alkalmazza tanulása során. Az érzelmekre hagyatkozás is közepes mértékben jellemző $(48,2 \%)$, hasonlóan a körülményekre való hagyatkozáshoz $(42,2 \%)$, míg a túlkészülés közepes mértékben a hallgatók többségére $(59 \%)$ volt jellemző. Az adatokból tehát jól kirajzolódik, hogy az egyetemre belépő hallgatók legnagyobb arányban a memorizálás stratégiáját alkalmazzák a tanulás során. Ugyanakkor a jelen vizsgálatban a memorizálás mellett jellemző a tanulásra fordított idő megtervezése, illetve a külső erőforrások közül még a segítségkérés, a belső erőforrások közül az erőfeszítés kontrollja, illetve közepes mértékben a túlkészülés. 
1. táblázat. Az elsőéves hallgatók tanulási stratégiái (\%-os megoszlás)

\begin{tabular}{|l|c|c|c|}
\hline Tanulási stratégiák & Alacsony & Közepes & Magas \\
\hline Memorizálás & 4,8 & 21,0 & 74,2 \\
\hline Kidolgozás/megszervezés & 26,2 & 41,3 & 32,5 \\
\hline Tervezés & 6,8 & 33,2 & 60,1 \\
\hline Monitorozás & 37,2 & 35,6 & 27,2 \\
\hline Erőfeszítés-kontroll & 7,6 & 37,0 & 55,4 \\
\hline Segítségkérés & 7,6 & 23,9 & 68,5 \\
\hline Halogatás & 19,2 & 46,2 & 34,6 \\
\hline Érzelmekre hagyatkozás & 31,7 & 48,2 & 20,1 \\
\hline Körülményekre hagyatkozás & 28,4 & 42,2 & 29,4 \\
\hline Túlkészülés & 12,4 & 59,0 & 28,6 \\
\hline
\end{tabular}

A tanulási motívumok eloszlása esetében (2. táblázat) a magas elsajátítási motívum a hallgatók többségére $(85,9 \%)$, a teljesítménykereső motívum magas $(54,7 \%)$ és közepes szintje $(31,7 \%)$ szintén a hallgatók többségére jellemző. A teljesítménykerülö motívum alacsony szinten a hallgatók 58\%-ánál jelenik meg, hasonlóan a negatív tanulási önhatékonysághoz, melynek alacsony szintje a minta 82,2\%-ára jellemző. A szóbeli megnyilvánulásoktól való szorongás eloszlása egyenletesebbnek mondható, ugyanakkor összességében közepes és magas szinten a hallgatók többségénél megjelenik (előbbi 32,6\%, utóbbi 41,6\%-ban), a pozitív tanulási önhatékonyság szintén közepes és magas szinten többségben jelenik meg (előbbi 46\%, utóbbi 44,8\%). Összességében tehát jól látható, hogy az elsajátítási motívum a legjellemzőbb a vizsgált mintában, vagyis a hallgatók elsősorban képességeik, tudásuk fejlesztése céljából tanulnak. Emellett jellemző rájuk a teljesítménykereső motívum is, mely azt jelenti, hogy a jegyekért, elismerésért, az eredményért tanulnak, továbbá hisznek saját képességeikben és hatékonyságukban, erre utal a pozitív tanulási önhatékonyság közepes és magas, illetve a negatív tanulási önhatékonyság alacsony szintje a hallgatók többségénél.

2. táblázat. Az elsőéves hallgatók tanulási motívumai (\%-os megoszlás)

\begin{tabular}{|l|c|c|c|}
\hline Tanulási motívumok & Alacsony & Közepes & Magas \\
\hline Elsajátítási motívum & 0,8 & 13,3 & 85,9 \\
\hline Teljesítménykereső motívum & 13,6 & 31,7 & 54,7 \\
\hline Teljesítménykerülő motívum & 58,0 & 30,6 & 11,4 \\
\hline Szorongás szóbeli megnyilvánulástól & 25,9 & 32,6 & 41,6 \\
\hline Pozitív tanulási önhatékonyság & 9,2 & 46,0 & 44,8 \\
\hline Negatív tanulási önhatékonyság & 82,2 & 15,8 & 2,0 \\
\hline
\end{tabular}

A tanulási attitüd kapcsán vizsgáltuk azokat a tényezőket, amelyek a tanuláshoz való viszonyulásukat mérik fel az egyetemi hallgatóknak (3. táblázat). Az eredmények alapján kirajzolódik, hogy a hallgatók többsége magas szorgalommal (57,9\%), magas akadémiai önhatékonysággal $(71,4 \%)$ jellemzi önmagát. Hasonlóan a tanulási motívumok esetében a szorongáshoz, a feladathelyzetekben mutatott tesztszorongás közepes és magas szintje is jellemző a hallgatók többségére (közepes szinten 34,2\%, magas szinten 47,9\% 
jellemző). A szervezés, elsősorban a tananyag és a hallgatók előtt álló feladatok szervezése is közepes és magas szinten jellemző a hallgatók nagy többségére. A társas helyzetekben megjelenő tárgyalás magas szintjével a hallgatók $82,1 \%$-a jellemezte magát, mely elsősorban a társak közötti ötletelésre, véleménycserére vonatkozik. A csoportmunkában a vezetés magas szintje $(53,1 \%)$ és az együttmúködés magas szintje $(53,1 \%)$ is a hallgatók többségére jellemző.

3. táblázat. Az elsőéves hallgatók tanulási attitüdje (\%-os megoszlás)

\begin{tabular}{|l|c|c|c|}
\hline $\begin{array}{l}\text { Tanulási } \\
\text { attitüd }\end{array}$ & Alacsony & Közepes & Magas \\
\hline Szorgalom & 7,4 & 34,8 & 57,9 \\
\hline Szervezés & 9,8 & 41,7 & 48,5 \\
\hline Tesztszorongás & 17,8 & 34,2 & 47,9 \\
\hline $\begin{array}{l}\text { Akadémiai } \\
\text { önhatékonyság }\end{array}$ & 1,2 & 27,4 & 71,4 \\
\hline Együttmúködés & 13,3 & 36,0 & 50,7 \\
\hline Vezetés & 10,4 & 36,5 & 53,1 \\
\hline Tárgyalás & 0,9 & 17,0 & 82,1 \\
\hline
\end{tabular}

A hallgatók én-attitüdjének vizsgálatakor négy tényezőt elemeztünk (4. táblázat). A hallgatók többségére $(58,1 \%)$ jellemzö, hogy elégedettek az életükkel, az új szituációkhoz való rugalmas alkalmazkodás magas szintje a hallgatók 55,6\%-ára jellemző. A problémák megoldására való nyitottságot is nagy mértékben $(68,4 \%)$ jellemzönek tekintették magukra a hallgatók, míg a feladathelyzetekben való kitartás közepes mértékben a minta 47,5\%-ára, magas szinten a hallgatók 44,7\%-ára jellemző. Az én-attitüdök kapcsán a hallgatók körében jellemzö az életükkel való elégedettség érzése, a nyitottság és a rugalmas alkalmazkodás a problémahelyzetekhez, illetve a kitartás legalább közepes mértékben. Mindezek a tényezők az egyetemi tanulmányi előmenetelben és eredményességben olyan személyes erőforrásoknak is tekinthetők, melyek segíthetik a hallgatókat az új kihívásokhoz való alkalmazkodásban.
A hallgatók én-attitúdjének vizsgálatakor négy tényezót elemeztünk (4. táblázat). A hallgatók többségére (58,1\%) jellemzó, hogy elégedettek az életükkel, az új szituációkhoz való rugalmas alkalmazkodás magas szintje a hallgatók 55,6\%-ára jellemzó. A problémák megoldására való nyitottságot is nagy mértékben (68,4\%) jellemzónek tekintették magukra a hallgatók, míg a feladathelyzetekben való kitartás közepes mértékben a minta 47,5\%-ára, magas szinten a hallgatók 44,7\%-ára jellemzó. Az én-attitúdök kapcsán a hallgatók körében jellemzố az életükkel való elégedettség érzése, a nyitottság és a rugalmas alkalmazkodás a problémahelyzetekhez, illetve a kitartás legalább közepes mértékben. Mindezek a tényezók az egyetemi tanulmányi elómenetelben és eredményességben olyan személyes eróforrásoknak is tekinthetók, melyek segithetik a hallgatókat az új kihivásokhoz való alkalmazkodásban. 
4. táblázat. Az elsöéves hallgatók én-attitüdje (\%-os megoszlás)

\begin{tabular}{|l|c|c|c|}
\hline Én-attitüd & Alacsony & Közepes & Magas \\
\hline Élettel való elégedettség & 10,1 & 31,8 & 58,1 \\
\hline Rugalmasság & 1,0 & 43,4 & 55,6 \\
\hline Nyitottság problémamegoldásra & 2,8 & 28,7 & 68,4 \\
\hline Kitartás & 7,8 & 47,5 & 44,7 \\
\hline
\end{tabular}

\section{A hallgatók tanulási mintázata}

Az összes vizsgált tényező bevonásával, exploratív faktorelemzés segítségével ellenöriztük a látens struktúrát (5. táblázat), aminek eredményeként öt fökomponens jött létre $(\mathrm{KMO}=0,870$; megmagyarázott variancia $=57,66 \%)$. Erre egyrészt azért volt szükség, mert túl sok változónk volt, másrészt pedig ezáltal alakíthattuk ki a stratégiák, motívumok és attitűdök összekapcsolásából létrejött tanulási mintázatot. A létrejött öt főkomponens mindegyike könnyen értelmezhető kategóriákat foglal össze. Az első csoportot erőfeszítésen alapuló szervezett tanulásnak neveztük el, amibe beletartozott minden olyan tanulási stratégia (pl. időgazdálkodás, memorizálás, erőfeszítés-kontroll) és attitüd (pl. szorgalom), ami nagyobb erőfeszítést igényel a tanulás során. A második csoportot maladaptív tanulásnak neveztük, és olyan változók kerültek ide, amelyek alapvetően nem-hatékony stratégiáknak (pl. halogatás, érzelmekre hagyatkozás) tekinthetők, valamint fordított értékekkel bekerült az élettel való elégedettség (elégedetlenség) és a monitorozás (hiánya) is. A harmadik csoport a magabiztosságon alapuló fejlődésre törekvés elnevezést kapta, amiben pozitív, fejlődési motívumok (pl. akadémiai és pozitív önhatékonyság, elsajátítási motívum) és a problémák iránti nyitottság, a problémamegoldásra való törekvés jelenik meg. A negyedik csoport az együttmüködés és rugalmasság elnevezéssel a társas stratégiákat (pl. együttműködés, segítségkérés), valamint a különböző váratlan szituációkhoz való rugalmas alkalmazkodást foglalta magában. Az ötödik csoport a teljesítményorientáció elnevezést kapta, és itt a teljesítménnyel kapcsolatos két orientáció (keresés, kerülés) tartozott össze.

5. táblázat. A tanulási mintázat kialakitása (faktorelemzés, faktorsúlyok)

\begin{tabular}{|l|c|c|c|c|c|}
\hline \multirow{2}{*}{ Változók } & \multicolumn{5}{|c|}{ Komponens } \\
\cline { 2 - 6 } & $\mathbf{1}$ & $\mathbf{2}$ & $\mathbf{3}$ & $\mathbf{4}$ & $\mathbf{5}$ \\
\hline Szorgalom & $\mathbf{0 , 7 9}$ & $-0,06$ & 0,21 & 0,06 & 0,10 \\
\hline Időgazdálkodás & $\mathbf{0 , 7 7}$ & $-0,22$ & 0,12 & 0,09 & 0,11 \\
\hline Szervezés & $\mathbf{0 , 7 0}$ & 0,02 & $-0,03$ & 0,00 & 0,03 \\
\hline Erőfeszítés-kontroll & $\mathbf{0 , 6 8}$ & 0,02 & 0,22 & 0,14 & 0,01 \\
\hline Tervezés & $\mathbf{0 , 6 8}$ & $-0,09$ & 0,23 & 0,17 & $-0,09$ \\
\hline Túlkészülés & $\mathbf{0 , 6 5}$ & 0,19 & 0,11 & 0,23 & 0,20 \\
\hline Kitartás & $\mathbf{0 , 5 7}$ & $-0,29$ & 0,41 & 0,10 & $-0,04$ \\
\hline Memorizálás & $\mathbf{0 , 5 5}$ & 0,09 & 0,06 & 0,20 & $-0,01$ \\
\hline Érzelmekre hagyatkozás & $-0,09$ & $\mathbf{0 , 8 6}$ & $-0,15$ & $-0,03$ & 0,17 \\
\hline Tesztszorongás & 0,24 & $\mathbf{0 , 7 7}$ & $-0,19$ & 0,07 & 0,17 \\
\hline Szorongás szóbeli megnyilvánulástól & 0,08 & $\mathbf{0 , 7 1}$ & $-0,11$ & $-0,10$ & 0,17 \\
\hline
\end{tabular}


D. Molnár Éva - Gál Zita: Egyetemi tanulmányaikat megkezdő hallgatók tanulási mintázata és tanulói profilja

\begin{tabular}{|l|c|c|c|c|c|}
\hline \multirow{2}{*}{ Változók } & \multicolumn{5}{|c|}{ Komponens } \\
\cline { 2 - 6 } & $\mathbf{1}$ & $\mathbf{2}$ & $\mathbf{3}$ & $\mathbf{4}$ & $\mathbf{5}$ \\
\hline Élettel való elégedettség & 0,19 & $\mathbf{- 0 , 5 5}$ & 0,04 & 0,21 & 0,15 \\
\hline Negatív önhatékonyság & $-0,12$ & $\mathbf{0 , 5 3}$ & $-0,53$ & $-0,07$ & 0,35 \\
\hline Monitorozás & 0,37 & $\mathbf{- 0 , 5 3}$ & 0,08 & $-0,13$ & 0,02 \\
\hline Körülményekre hagyatkozás & $-0,62$ & $\mathbf{0 , 4 6}$ & 0,09 & 0,12 & 0,14 \\
\hline Halogatás & $-0,42$ & $\mathbf{0 , 4 2}$ & 0,25 & 0,09 & $-0,07$ \\
\hline Nyitottság problémamegoldásra & 0,15 & $-0,08$ & $\mathbf{0 , 7 8}$ & 0,23 & $-0,00$ \\
\hline Pozitív önhatékonyság & 0,15 & $-0,26$ & $\mathbf{0 , 7 6}$ & 0,03 & 0,10 \\
\hline Akadémiai önhatékonyság & 0,18 & $-0,11$ & $\mathbf{0 , 5 9}$ & 0,18 & 0,06 \\
\hline Elsajátítási motívum & 0,52 & 0,06 & $\mathbf{0 , 4 9}$ & 0,26 & 0,10 \\
\hline Együttmüködés & 0,04 & $-0,15$ & $-0,09$ & $\mathbf{0 , 8 3}$ & 0,17 \\
\hline Tárgyalás & 0,21 & 0,08 & 0,18 & $\mathbf{0 , 7 1}$ & $-0,17$ \\
\hline Vezetés & 0,12 & $-0,20$ & 0,26 & $\mathbf{0 , 7 0}$ & 0,19 \\
\hline Rugalmasság & 0,04 & 0,05 & 0,21 & $\mathbf{0 , 5 6}$ & 0,06 \\
\hline Segítségkérés & 0,38 & 0,02 & 0,09 & $\mathbf{0 , 5 3}$ & $-0,21$ \\
\hline Teljesítménykerülő motívum & 0,06 & 0,30 & 0,01 & 0,06 & $\mathbf{0 , 7 9}$ \\
\hline Teljesítménykereső motívum & 0,20 & 0,11 & 0,50 & 0,12 & $\mathbf{0 , 6 2}$ \\
\hline
\end{tabular}

A tanulási mintázatok és a mérésbe bevont kognitív képességek, valamint a felvételi pontszám közötti összefüggések vizsgálata kapcsán több szignifikáns, gyenge kapcsolat mutatható ki (6. táblázat). A problémamegoldó gondolkodás kivételével minden tényezővel szignifikáns összefüggést mutat a magabiztosságon alapuló fejlődésre törekvés mintázat, ami azt mutatja, hogy a tanulók önhatékonysága, megértésre és fejlödésre való törekvése pozitívan függ össze a magasabb kognitív képességekkel és jobb felvételi pontszámmal. Ezen kívül még az erőfeszítésen alapuló szervezett tanulás és a teljesítésorientáció mintázatok mutatnak több szignifikáns kapcsolatot a kognitív képességekkel és felvételi pontszámmal.

6. táblázat. A tanulási mintázatok összefüggései a vizsgált képességekkel, felvételi pontszámmal

\begin{tabular}{|l|c|c|c|c|c|c|c|}
\hline $\mathbf{r}$ & $\begin{array}{c}\text { Mate- } \\
\text { matika }\end{array}$ & Olvasás & $\begin{array}{c}\text { Probléma- } \\
\text { megoldás }\end{array}$ & Memória & Induktív & $\begin{array}{c}\text { Kombi- } \\
\text { natív }\end{array}$ & $\begin{array}{c}\text { Felvételi } \\
\text { pont }\end{array}$ \\
\hline $\begin{array}{l}\text { Erőfeszítésen } \\
\text { alapuló szervezett } \\
\text { tanulás }\end{array}$ & $-0,04$ & $-0,03$ & $-0,23 * *$ & $-0,09 *$ & $-0,10^{* *}$ & $-0,02$ & $0,20 * *$ \\
\hline Maladaptív tanulás & $-0,02$ & $-0,01$ & 0,00 & $-0,08^{*}$ & $-0,05$ & $-0,01$ & $-0,06$ \\
\hline $\begin{array}{l}\text { Magabiztosságon } \\
\text { alapuló fejlődésre } \\
\text { törekvés }\end{array}$ & $0,19 * *$ & $0,19 * *$ & 0,06 & $0,14^{* *}$ & $0,15^{* *}$ & $0,13 * *$ & $0,25^{* *}$ \\
\hline $\begin{array}{l}\text { Együttmúködés és } \\
\text { rugalmasság }\end{array}$ & $-0,01$ & $-0,08^{*}$ & $-0,10$ & $-0,04$ & $-0,03$ & 0,03 & $-0,03$ \\
\hline Teljesítésorientáció & $0,08 * *$ & 0,02 & $-0,04$ & $-0,03$ & 0,00 & 0,03 & $0,11 * *$ \\
\hline
\end{tabular}

$* * \mathrm{p} \leq 0,01 ; * \mathrm{p}<0,05$ 
A tanulási mintázatok és a felvételi pontszám közötti összefüggés további értelmezéséhez ellenőriztük, hogy a tanulási mintázatok (alacsony, közepes vagy magas szinten jellemző-e a hallgatókra) alapján van-e különbség a felvételi pontszámban (7. táblázat). Három esetben találtunk szignifikáns különbséget: azok a hallgatók, akikre magas szinten jellemző az erőfeszítéses tanulás, a magabiztos fejlődésre törekvés és a teljesítésorientáció, szignifikánsan magasabb felvételi pontszámmal jutottak be az egyetemre, mint azok, akikre ezek a tanulási mintázatok nem, vagy közepesen jellemzőek.

7. táblázat. A felvételi pontszámok alakulása a tanulási mintázatok alapján

\begin{tabular}{|l|c|c|c|c|c|}
\hline \multirow{2}{*}{ Tanulási mintázatok } & \multirow{2}{*}{ Alacsony } & \multirow{2}{*}{$\begin{array}{c}\text { Köze- } \\
\text { pes }\end{array}$} & \multirow{2}{*}{ Magas } & \multicolumn{2}{c|}{ Anova } \\
\cline { 5 - 7 } & & & $\mathbf{F}$ & $\mathbf{p}$ \\
\hline Eröfeszítéses, szervezett tanulás & 353 & 377 & 391 & 11,71 & 0,00 \\
\hline Magabiztosság, fejlődésre törekvés & 378 & 369 & 393 & 21,40 & 0,00 \\
\hline Együttmüködés, rugalmasság & 379 & 385 & 384 & 0,05 & n.s. \\
\hline Maladaptív tanulás & 388 & 382 & 384 & 0,84 & n.s. \\
\hline Teljesítésorientáció & 376 & 385 & 392 & 6,09 & 0,00 \\
\hline
\end{tabular}

\section{Hallgatói csoportok azonositása}

A vizsgálatunk egyik kutatási célja volt a lemorzsolódás szempontjából veszélyeztetett tanulói csoportok beazonosítása, amihez klaszterelemzést (hierarchikus, K-means) végeztünk a kialakított tanulási mintázatok alapján. Hat klaszter rajzolódott ki (1. ábra), ami jól mutatja, hogy az egyes tanulási mintázatok hogyan, milyen módon jellemzők az adott hallgatói csoportra. A lemorzsolódás szempontjából nem veszélyeztetettek az 1. csoportba tartozók, akiket „együttműködő, fejlődés-orientáltnak” nevezhetnénk el, hiszen jellemzők rájuk a pozitív tanulási mintázatok, de nem jellemző a maladaptív tanulás. A hallgatók 14 százaléka esik ebbe a csoportba. A harmadik és a hatodik hallgatói csoport sem tekinthető veszélyeztetettnek, míg az előbbi az első csoporthoz hasonló jellemzőkkel rendelkezik alacsonyabb szinten ( $22 \%$-a a hallgatóknak), az utóbbi csoport (14\%) minden tanulási mintázatban magas értékeket mutatott, ami egyfajta tökéletességre való törekvést jelez, minden tanulási mintázat jellemző rájuk.

„Rosszul tanulóknak” nevezhetjük el az ötödik hallgatói csoportot (16\%), akikre csak a maladaptív tanulás jellemző, a többi, pozitív tanulási mintázat nem jellemző rájuk (sem nem törekednek a fejlődésre, eredmények elérésére, sem pedig nem jellemző rájuk a rugalmas együttműködés). A negyedik hallgatói csoport (17\%) is bekerülhet ebbe az elnevezésbe, azonban az ötödik csoporttal szemben, a maladaptív tanulás mellett jellemző rájuk a teljesítésorientáció is, ami azt jelenti, hogy bár rossz tanulási stratégiákkal rendelkeznek (halogatnak, elégedetlenek, nem bíznak képességeikben, magas szorongásúak), de fontos nekik a teljesítmény.

A hallgatói csoportok közül a második csoportot „lézengőknek” hívhatjuk, akikre semmi nem jellemző, de leginkább a teljesítésorientáció nem. Sem nem jellemző rájuk a fejlődésre, megértésre való törekvés, sem az erőfeszítéses tanulás, de még a maladaptív tanulás sem. A vizsgálatunkban részt vett hallgatók 17 százaléka került ebbe a csoportba. A lemorzsolódás szempontjából a „lézengők” és a „rosszul tanulók” csoportjait érdemes figyelembe venni, hiszen ők vannak leginkább kitéve a valószínüsíthetö kudarcoknak.

A felvételi pontszám, matematika és olvasás esetében szignifikánsan különböző eredményeket értek el az egyes hallgatói csoportok. Mindhárom esetben az első csoport, az 
„együttmúködő és fejlődés-orientáltak” szignifikánsan magasabb teljesítményt mutattak, mint a második (,lézengők”) és ötödik (,rosszul tanulók”) csoportja: $\{1\}>\{2\}\{5\}$ $\mathrm{F}=3.907, \mathrm{p}=0,00$.

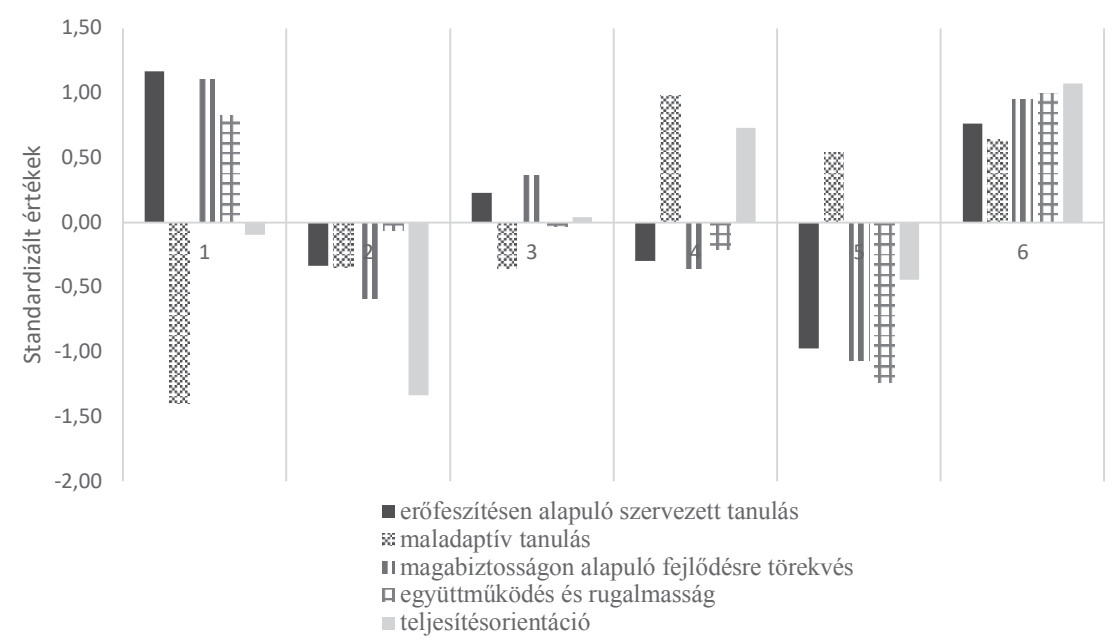

1. ábra. Hallgatói profilok a tanulási mintázatok alapján

\section{Összegzés}

Az eredményeink alapján az egyetemi tanulmányaikat kezdö hallgatók legnagyobb arányban a memorizálás stratégiáját alkalmazzák a tanulás során, azonban a memorizálás mellett jellemző rájuk a metakognitív stratégiák közül a tanulásra fordított idő megtervezése, illetve az erőforrások alkalmazása közül a segítségkérés, az erőfeszítés kontrollja, illetve közepes mértékben a túlkészülés. Vagyis a hallgatók körében az elsajátítandó tananyag ismételgetéssel való rögzítése, a tanulási folyamat tervezése, szükség esetén a segítségkérés, illetve az erőfeszítés-kontroll, a túlkészülés, a halogatás is jellemző saját tanulási folyamatukra. A hallgatókat elsősorban a képességeik, tudásuk fejlesztése motiválja a tanulásra, hisznek saját képességeikben, ugyanakkor megjelenik az eredményért, érdemjegyért való tanulás is.

Eredményeink a szakirodalommal összhangban (1. Tanaka és Murayama, 2014) bebizonyították a hatékony tanulási stratégiák és motívumok pozitív összefüggéseit a tanulmányi eredményességgel és egyes kognitív képességekkel. A magas önhatékonyság, a megértésre és fejlődésre való törekvés szignifikánsan összefügg a felvételi pontszám eredményekkel, azok, akikre jobban jellemzők ezek a motívumok, magasabb pontszámmal jutottak be az egyetemre.

A lemorzsolódás szempontjából a vizsgálatban résztvevő hallgatók közül 32\%-kal érdemes a jövőben foglalkozni, hiszen ezek közül 17\% vagy csak lézeng az egyetemen, vagy pedig nem-hatékony tanulási mintázattal rendelkezik (16\%). Eredményeink alátámasztják a szakirodalomban találtakat, mi szerint azok, akik nem eléggé elkötelezettek az egyetemi tanulmányok iránt, akikre jellemző a magas szorongás és maladaptív tanulási stratégiák használata, fokozottan ki vannak téve a kiégés, kudarc és lemorzsolódás veszélyének (Wang és Eccles, 2012). A jövőben olyan tanulásmódszertani fejlesztésre van szükség, ami által a hallgatók felismerhetik rossz tanulási stratégiáikat, és egyben elsajátíthatnak hatékonyabb, a megértést és fejlődést elősegítő tanulási stratégiákat. 
Mindazonáltal érdemes olyan oktatási módszereket is alkalmazni, ami által az egyetemi tanulmányok iránt elkötelezett, együttmüködő és fejlődésre törekvő attitüd alakítható ki a hallgatókban.

\section{Irodalom}

Alkan, N. (2014). Humor, loneliness and acceptance: Predictors of university drop-out Intentions. Procedia - Social and Behavioral Sciences, 152, 1079-1086. DOI: $10.1016 /$ j.sbspro.2014.09.278

Csapó, B. és Molnár, Gy. (2017). Potential for Assessing Dynamic Problem-Solving at the Beginning of Higher Education Studies. Frontiers in Psychology, 8(2022), 1-12. DOI: 10.3389/fpsyg.2017.02022

D. Molnár, É. (2013). Tudatos fejlödés. Az önszabályozott tanulás elmélete és gyakorlata. Budapest: Akadémiai Kiadó. https://mersz.hu/?kdid=266

D. Molnár, É \& Gál, Z. (2017). TAMS - Tanulási attitüdök, motívumok és stratégiák. Tesztdokumentáció. Kézirat.

Eckert, M., Ebert, D., Lehr, D., Sieland, B. \& Berking, M. (2016). Overcome procrastination: Enhancing emotion regulation skills reduce procrastination. Learning and Individual Differences, 52, 10-18. DOI: 10.1016/j.lindif.2016.10.001

Entwistle, N. \& Ramsden, P. (1983). Understanding student learning. London: Croom Helm.

Fejes, J. B. (2015). Célok és motiváció. Tanulási motiváció a célorientációs elmélet alapján. Budapest: Gondolat Kiadó.

Forbes, A. \& Wickens, E. (2005). A good social live helps students to stay the course. Times High Education Supplement, 1676, 58-63.

Gadbois, S. \& Sturgeon, R. (2011). Academic self-handicapping: Relationships with learning specific and general self-perceptions and academic performance over time. British Journal of Educational Psychology, 81(2), 207-222. DOI: 10.1348/000709910X522186

Hartwig, M.K. \& Dunlosky, J. (2012). Study strategies of college students: Are self-testing and scheduling related to achievement? Psychonomic Bulletin \& Review, 19(1), 126-134.

Hódi, Á. és Tóth, E. (2019). Elsőéves egyetemi hallgatók szövegértés fejlettsége és olvasási attitüdjei. Iskolakultúra, 29(1), 55-67.

Jadidi, F., Mohammadkhani, S. \& Tajrishi, K. (2011). Perfectionism and Academic Procrastination. Procedia - Social and Behavioral Sciences, 30, 534-537. DOI: $10.1016 /$ j.sbspro.2011.10.104

Ketonen, E., Dietrich, J., Moeller, J., Salmela-Aro, K. \& Lonka, K. (2018). The role of daily autonomous and controlled educational goals in students' academic emotion states: An experience sampling method approach. Learning and Instruction, 53, 10-20. DOI: 10.1016/j.learninstruc.2017.07.003

Ketonen, E. E., Malmberg, L.-E., Salmela-Aro, K., Muukkonen, H., Tuominen, H. \& Lonka, K. (2018). The role of study engagement in university students' daily experiences: A multilevel test of moderation. Learning and Individual Differences, megjelenés alatt. DOI: 10.1016/j.lindif.2018.11.001

Latham, G. P. \& Locke, E. A. (1991). Self-regulation through goal setting. Organizational Behavior and Human Decision Processes, 50, 212-247. DOI: 10.1016/0749-5978(91)90021-K

Linnenbrink, E. A. \& Pintrich, P. R. (2002). Achievement goal theory and affect: An asymmetrical bidirectional model. Educational Psychologist, 37, 69-78. DOI: 10.1207/S15326985EP3702 2

Molnár, É. (2002). Önszabályozó tanulás: nemzetközi kutatási irányzatok és tendenciák. Magyar Pedagógia, 102(1), 63-77.

Molnár, G. (2019). Nőtt az egyetemi tanulmányaikat kezdő diákok tanulási potenciálja és problémamegoldó képessége: években mérhetö különbségek a diákok között. Iskolakultúra, 29(1), 3-16.

Molnár, G. \& Csapó, B. (2019). A felsőoktatási tanulmányi alkalmasság értékelésére kidolgozott rendszer a Szegedi Tudományegyetemen: elméleti keretek és mérési eredmények. Educatio, megjelenés alatt.

Molnár, G., Makay, G. \& Ancsin, G. (2018). Feladat- és tesztszerkesztés az eDia rendszerben. Szeged: SZTE Oktatáselméleti Kutatócsoport.

OECD (2016). PISA 2015 Results (Volume II): Policies and Practices for Succesfull Schools. OECD Publishing.

Paris , S. G. \& Paris, A. H. (2001). Classroom applications of research on self-regulated learning. Educational Psychologist, 36(2), 89-101. DOI: 10.1207/ S15326985EP3602 4

Pásztor, A. (2019). Induktív és kombinatív gondolkodás fejlettségének online vizsgálata egyetemi tanulmányaikat kezdő hallgatók körében. Iskolakultúra, 29(1), 42-54.

Pintrich, P. R. (1999). The role of motivation in promoting and sustaining self-regulated learning. International Journal of Educational Research, 31, 459-469. DOI: 10.1016/S0883-0355(99)00015-4

Pintrich, P. R. (2000). The role of goal orientation in self-regulated learning. In Boekaerts, M., Pintrich, P. R. \& Zeidner, M. (szerk.), Handbook of 
self-regulation. Orlando, FL: Academic Press. 451502. DOI: 10.1016/b978-012109890-2/50043-3

Pintrich, P. R. (2004). A Conceptual Framework for Assessing Motivation and Self-Regulated Learning in College Students. Educational Psychology Review, 16, 385-407. DOI: 10.1007/s10648-004-0006-x

Tanaka, A. \& Murayama, K. (2014). Within-person analyses of situational interest and boredom: Interactions between task-specific perceptions and achievement goals. Journal of Educational Psychology, 106, 1122-1134. DOI: 10.1037/a0036659

Tinto, V. (2010). From theory to action: Exploring the institutional conditions for student retention. In Higher education: Handbook of Theory and Research. Springer Netherlands. 51-89. DOI: 10.1007/978-90481-8598-6_2
Wang, M. T. \& Eccles, J. S. (2012). Social support matters: longitudinal effects of social support on three dimensions of school engagement from middle to high school. Child Development, 83(3), 877-895. DOI: $10.1111 / \mathrm{j} .1467-8624.2012 .01745 . x$

Weinstein, C. E., Husman, J. \& Dierking, D. R. (2000). Self- regulation interventions with a focus in learning strategies. In Boekaerts, M., Pintrich, P. R. \& Zeidner, M. (szerk.), Handbook of self-regulation. Orlando, FL: Academic Press. 727-747. DOI: 10.1016/b978-012109890-2/50051-2

Winne, P. \& Perry, N. (2000). Measuring self-regulated learning. In Boekaerts, M., Pintrich, P. R. \& Zeidner, M. (szerk.), Handbook of self-regulation. Orlando, FL: Academic Press. 531-566. DOI: 10.1016/b978-012109890-2/50045-7

\title{
Köszönetnyilvánítás, támogatás \\ A kutatás megvalósítását az EFOP-3.4.3-16-2016-00014 pályázat támogatta.
}

\begin{abstract}
Absztrakt
Számos nemzetközi kutatás foglalkozik azoknak a jellemzöknek az azonosításával, melyek segítségével jobban megérthető az egyetemi lemorzsolódás jelensége. A vizsgálatok többségében a lemorzsolódást magyarázó egyéni jellemzők közül a hallgatók tanulási stratégiái, szokásai, tanulási énképe, motivációja és a tanuláshoz való hozzáállásuk kerül középpontba. Kutatásunkban a Szegedi Tudományegyetem bemeneti kompetenciamérésének keretében vizsgáltuk az egyetemre belépő elsőéves hallgatók egyéni jellemzőit. Vizsgálatunkban 1359 fő egyetemi tanulmányaikat megkezdő hallgató vett részt. A hallgatók tanulási stratégiáit, motívumait és attitüdjeit a saját fejlesztésủ TAMS - Tanulási attitűdök, motívumok és stratégiák kérdőívcsomaggal mértük. Az eredmények alapján az egyetemre belépő hallgatók nagy arányban (74\%) magas szinten használják a memorizálás stratégiáját, ugyanakkor a segítségkérés (69\%-ukra), tervezés $(60 \%$-ukra) is jellemző tanulásukra, továbbá pozitív motivációs mintázatot mutatnak (elsajátítási motívum magas szintje $86 \%$-ra, az akadémiai önhatékonyság magas szintje 71\%-ra, a másokkal való együttmüködés $82 \%$-ra jellemző). Eredményeink szerint a magabiztosságon alapuló fejlődésre törekvés pozitív összefüggéseket mutat a bemeneti mérés során vizsgált kognitív képességekkel és a felvételi pontszámmal. A tanulói mintázatok alapján a lemorzsolódás szempontjából föként azon tanulói csoportok lehetnek veszélyeztetettek, akik rosszul tanulnak (magas maladaptív tanulási attitűddel rendelkeznek, miközben alacsony az erőfeszítéses tanulásuk, a fejlődésre törekvésük és az együttműködésük is). Mindemellett a hallgatók 17\%ra jellemző „lézengők” csoportja is külön figyelmet igényel, akiket a tanulás nem, csak a társas együttlét, a másokkal való jó kapcsolat motivál valamennyire. Kutatásunk céljának megfelelően feltártuk a tanulmányaikat megkezdő hallgatók tanulási és tanulói mintázatait, azonosítottuk a lemorzsolódás szempontjából veszélyeztetett csoportokat, ami a tanulásfejlesztés terén jelölhet ki feladatokat a jövőben.
\end{abstract}

